\title{
Music as a transpersonal care tool - perceptions of hospitalized people assisted in the university extension
}

\author{
A música como instrumento de cuidado transpessoal - percepçōes de indivíduos hospitalizados assistidos \\ na extensão universitária

\section{La música como instrumento de cuidado transpersonal - percepciones de individuos hospitalizados asistidos} \\ en la extensión universitaria
}

\author{
Emanuelle Caires Dias Araújo Nunes ${ }^{1,2}$ (D) \\ Fabiana Aguiar de Oliveira ${ }^{1}$ (ic \\ Juliana Xavier Pinheiro da Cunha ${ }^{1}$ (D) \\ Sabrina Oliveira Reis ${ }^{1}$ (D) \\ Gizelia da Gama Meira ${ }^{1}$ (ID \\ Regina Szylit ${ }^{2}$ (i)
}

${ }^{1}$ Universidade Federal da Bahia, Instituto Multidisciplinar em Saúde. Vitória da Conquista, Bahia, BA, Brasil.

${ }^{2}$ Universidade de São Paulo, Escola de Enfermagem. São Paulo, SP, Brasil.
Corresponding author:

Emanuelle Caires Dias Araújo Nunes

E-mail: emanuelecdanunes@gmail.com

Submitted on $05 / 30 / 2019$

Accepted on 09/25/2019.

DOI: 10.1590/2177-9465-EAN-2019-0165

\begin{abstract}
Objective: to analyze the perception of hospitalized patients about the care received through an extensionist musical visit under the perspective of the Theory of Human Caring. Method: a descriptive-exploratory-qualitative research conducted in a hospital of the state of Bahia, with 15 hospitalized patients, interviewed within 24 hours after receiving the extensionist musica visit. Collection involved semi-structured interview, analyzed through Discourse of the Collective Subject. Results: three axes emerged: Musical Care at the interface with Transpersonal Care; Music as a rescue element of hope during hospitalization; and Beyond music - a meeting between care, art and human relations. The results show the feelings evoked during the experience of the musical visit and emphasize the importance of this activity. Conclusion and Implications for the practice: music as a Transpersonal Care strategy motivates patient-staff-family ties, encouraging optimism and hope by mobilizing feelings and sensations of body, mind and soul, enabling the emergence of resilient behaviors during the hospitalization process. The study promotes reflection and guidance for the most creative, sensitive and bold care in the hospital environment. It suggests greater use of music by the health staff - meeting a care extended to human needs that transcend the physical.
\end{abstract}

Keywords: Music; Care; Hospital; Extension.

\section{REsUMo}

Objetivo: analisar a percepção de pacientes hospitalizados sobre o cuidado recebido por meio de uma visita musical extensionista sob as lentes da Teoria do Cuidado Transpessoal. Método: pesquisa descritivo-exploratória-qualitativa realizada em um hospital baiano, com 15 pacientes hospitalizados, entrevistados até 24 horas após terem recebido a visita musical extensionista. A coleta envolveu entrevista semiestruturada, analisada mediante Discurso do Sujeito Coletivo. Resultados: emergiram 3 eixos: Cuidado Musical na interface com o Cuidado Transpessoal; $A$ música como elemento de resgate da esperança durante a hospitalização e Para além da música - um encontro entre cuidado, arte e relações humanas. Os resultados mostram os sentimentos evocados durante a vivência da visita musical e ressaltam a importância desta atividade. Conclusão e Implicações para a prática: a música como estratégia de cuidado transpessoal motiva os vínculos entre paciente-equipe-família, estimulando otimismo e esperança ao mobilizar sentimentos e sensações do corpo, da mente e da alma, viabilizando a emersão de comportamentos resilientes durante o processo de hospitalização. O estudo promove reflexão e orientação para o cuidado mais criativo, sensíve e ousado no ambiente hospitalar, sugerindo maior uso da música pela equipe de saúde - ao encontro de um cuidado ampliado às necessidades humanas que transcendem as físicas.

Palavras-chave: Música; Cuidado; Hospital; Extensão.

\section{REsumen}

Objetivo: analizar la percepción de los pacientes hospitalizados sobre la atención recibida a través de una visita musical extensionista bajo la lente de la Teoría del Cuidado Transpersonal. Método: investigación descriptiva-exploratoria-cualitativa realizada en un hospital de Bahia con 15 pacientes hospitalizados entrevistados hasta 24 horas después de haber recibido la visita musical extensionista. La recolección involucró entrevista semiestructurada, analizada mediante Discurso del Sujeto Colectivo. Resultados: convergieron en 3 ejes: Cuidado Musical en la interfaz con el Cuidado Transpersonal; La música como elemento de rescate de la esperanza durante la hospitalización; y, además de la música - un encuentro entre cuidado, arte y relaciones humanas. Estos mostraron los sentimientos evocados durante la vivencia de la visita musical y resaltaron la importancia de esta actividad. Conclusión e Implicaciones para la práctica: la música como estrategia de Cuidado Transpersonal motiva los vínculos entre paciente-equipo-familia, estimulando optimismo y esperanza al movilizar sentimientos y sensaciones del cuerpo mente y alma, posibilitando la emersión de comportamientos resilientes durante el proceso de hospitalización. El estudio promueve reflexión y orientación para un cuidado más creativo, sensible y audaz en el ambiente hospitalario, sugiriendo un mayor uso de la música por el equipo de salud al encuentro de un cuidado ampliado a las necesidades humanas que trascienden a las físicas.

Palabras clave: Música; Cuidado; Hospital; Extensión. 


\section{INTRODUCTION}

The word "music" comes from the Greek mousiké, which means art and science of combining sounds pleasant to the hearing. ${ }^{1}$ This concept extends to the understanding that music is part of the human being, an instrument of union that brings together people, families, customs and cultures and that cherishes the soul, providing moments of pleasure and well-being. ${ }^{2}$

In addition, music encourages brain areas such as the limbic system - the region responsible for mood, encouragement, affectivity, emotions and social behavior. Listening to any melody can give you a sense of well-being and pleasure that can in turn promote physical and psychological changes in the individual. ${ }^{3}$

Several situations, such as fear, discouragement, anxiety, worry, stress and longing, as well as physical aggravation, can affect a subject during his hospitalization period. As it provides serenity and greater acceptance of treatment and hospitalization, music is considered an instrument of non-pharmacological therapeutic effect. ${ }^{4}$

In this sense, it is referred to as music therapy. That is, the use of music in order to alternate, with physical and psychological discomfort, tranquility, well-being and some relief from anxiety, ${ }^{5}$ through its ability to affect the emotions, attitudes and behaviors that generate a resilient atmosphere. ${ }^{6}$

The Multidisciplinary Welcoming Grouping (AMA-Agrupamento Multidisciplinar de Acolhimento), an action of teaching-researchextension to care that faces the risk of hospital death, has, as one of its objectives to welcome families with hospitalized people at risk of death from the systematic praxis of transpersonal-systemic care. The project is formed by students of nursing and psychology courses at Universidade Federal da Bahia. Its performance setting is a public hospital in the countryside of the state of Bahia. Among the activities developed with families, is the Musical Visit inspired by Human Caring, which aims at the exercise of comprehensive care. That is, one capable of achieving the physical, mental and spiritual well-being of patients and their family.

This initiative meets the complex context of hospitalization involving physically and emotionally weak patients and families. Faced with an adversity, such as illness, they face a new process of self-knowledge, capable of revealing strategies for pain relief and resignification of the lived moment. Music, in this sense, represents an important device capable of providing relief, helping to evoke feelings and energy conducive to the optimism and hope needed in hospitalization moments. ${ }^{7}$

Several national and international studies indicate relevant benefits of adding music to care such as stress reduction, anxiety and pain; increased quality of life of patients and families; improvement of interpersonal relationships; and stress reduction typical of the hospital environment. . $^{3,8-10}$
In this sense, musical care is in tune with the perspective of Human Caring, by contrasting the overly centered model on technologies that undermine the real meaning of care. Given this reality, it is extremely important that, during health care, creative elements such as music are adopted, optimizing a humanized posture, focused on the loving gaze that, beyond the physical, understands the intersubjectivity of the subject. Watson's Human Caring aims for a caritas model capable of a deeper appreciation of human complexity and experiences, valuing the care of the human body-mind-soul. It achieves from inner immersions in its own life and from the development of intersubjective meanings and responses to care, healing, illness, despair, disease, and death. ${ }^{11-12}$

It is noteworthy that there are many contributions in the literature about the use of music in the health context. However, the relevance of this study is shown by its theoretical framework - Human Caring and the analytical context from the university extension. These characteristics are little observed in other research found in Scielo, LILACS and PubMed databases, in the last five years.

Thus, there is, as a problem, the question: "What is the meaning of care perceived by hospitalized patients after the experience of Musical Visit carried out by the extension project" Multidisciplinary Welcoming Grouping?".

From the guiding question, the general objective emerges to analyze the perception of hospitalized patients about the care received through an extensionist musical visit, under the perspective of the Theory of Human Caring. Knowing the perception of hospitalized patients of the care received through the musical visit and relating the musical care perceived through the musical visit with the theoretical assumptions of Human Caring are specific objectives.

\section{METHOD}

This is a descriptive exploratory research with a qualitative approach. It was held in a general hospital in the countryside of the state of Bahia, specifically in its sectors of medical and surgical internment, which have a total of 90 beds. The research followed the theoretical framework of Watson's Theory of Human Caring, treated in this study as Human Caring. As a methodological reference, we adopted the Theory of Social Representations that supports the analytical technique chosen. Such framework has a cognitive dimension, as it favors an experimentation of the world and the world for the construction of a reality common to a social group, being a specific way of understanding and communicating what is known. In this respect, music is a phenomenon that contributes to this social communication, to the exchange of linguistic and nonlinguistic messages between subjects and groups, which seek to abstract meaning from social interactions and to introduce order and perceptions assumed as significant in the world..$^{13-14}$ 
The study followed the procedures provided for in Resolution 466/12. Approval by the Research Ethics Committee was given in Opinion 2,647,073, of May 2018, involving 15 patients hospitalized in these sectors. Inclusion criteria were: having the patient received the musical visit of the AMA project for a maximum of 24 hours, enabling the recent memory of the feelings mobilized; to be lucid, oriented and with their preserved verbalization. The selection of participants was non-probabilistic in nature, as the choice was made by random methods, with the choice of the individuals most accessible to the researcher, following convenience parameters. The researcher responsible for the collection was part of the AMA project, however did not participate in the musical visit that would be a reference for data collection. Thus, she conducted the interviews within 24 hours after the musical visit, dressed differently from the members of the troupe, in order to disconnect her image from the activity to be analyzed. This interviewer had experience with the method and subject of the study, and addressed patients who were awake and had no complaints at the time. After confirming that the patient had received/participated in the musical visit, the researcher presented the research to him, inviting him individually, through the Informed Consent Form (ICF), to participate according to his personal desire. The consenting subjects signed the informed consent form and were interviewed at the bedside. All hospitalized patients next to each interviewee were excluded from the study invitation, in order to reduce influences on their discourse due to the spatial proximity between them. The interviews were recorded and later transcribed for full analysis. The total number of interviews was defined by theoretical data saturation.

The interview was semi-structured, with the following questions: "How is your internment experience here?"; "How was it for you to receive a musical visit here? "; "What did you feel while listening to the songs?"; and "What did this moment mean to you?".

Data analysis was performed through Discourse of the Collective Subject (DCS), which is a proposal for the organization and tabulation of qualitative verbal data based on the Theory of Social Representations. It endorses the sense of speech socially attributed to a group of people who have something in common, in this case hospitalization. DCS was chosen for organizing the data concisely but simultaneously in-depth by gathering as many expressions as possible from the subjects, according to the core ideas or anchors identified in the analysis process. Core ideas $(\mathrm{Cl})$ are linguistic expressions that accurately describe the meaning of the statement or a set of statements. Anchoring (AC) is an explicit linguistic manifestation of a given ideology or belief of the discourse author, which is used to frame a specific situation. $\mathrm{Cl}$ and $\mathrm{AC}$ function as themes that converge with speech categorization.
The key expressions (KE) are highlighted excerpts of the speech, which are organized according to the $\mathrm{Cl}$ or reference $\mathrm{AC}$, enabling the gathering of related excerpts, coming from different subjects, which converge in a single discourse, adjusted in the first person singular, although it carries expressions of multiple participants. Discourse of the Collective Subject (DCS) is the coherently arranged speech. ${ }^{15}$

\section{RESULTS}

The results of this research comprise 3 axes identified as: Musical Care at the interface with Transpersonal Care; Music as a rescue element of hope during hospitalization; and Beyond music - a meeting between care, art and human relations.

AXIS 1: Musical Care at the interface with Transpersonal Care

CI 1: Body: Music minimizes symptoms and improves physical perception

Music has the sense of bringing more comfort, all the time music is good. The hospitalization is being very good, because the hospital and the staff welcome us very well and I think it would be better if the staff brought more music to the hospital, because it even relieves the pain more (DCS 1).

CI 2: Mind: Music mobilizes hope and well-being

Music is too good, it lifts you up! It's boring to be here, but with music we feel a greater desire to live. I liked this singing, it cheers us up, it makes us happy, it felt so good, it made me forget the problems, it gave me a joy, a confidence, a desire to live. I have been hospitalized for months and it is the first time I am seeing, and it is a distraction for both patients and caregivers, because there comes a time when you are thinking things and then there is nothing to think, talk and no more to talk about, and the music soothes the mind, distracts a lot (DCS 2).

CI 3: Soul: music arouses good feelings and spirituality Ah, music is life, is joy, is peace, tranquility and, at the same time, I want to cry because I felt the presence of God, very good to experience it. The music gives a certain mood, you are sad then listen to the music and feel a relief, rejoices the soul, and has a very strong meaning to move the heart, serves to reflect, soothes you, music is everything, right? It makes you want to hear more and more (DCS 3).

The above DCS demonstrate the relationship made by respondents to Human Caring by evoking in their speech the comfort felt in relation to body, mind and soul - elements 
cherished by Watson's theory. Thus, DCS highlight the importance of musical activity within the hospital environment, which is able to promote pain relief and comfort to the patient and family. In this sense, there is the appreciation of playful activities, which reinforces the need for the health staff to innovate their care praxis in directing comprehensive and Human Caring to the individual.

AXIS 2: Music as a rescue element of hope during hospitalization

Cl 4: Positive memories

Music brings fond memories during this difficult time of being stuck here in the hospital. It allows me to feel joy, to remember and to relive good times that are not possible now, but that renew my hope to get out of this. That's why it's so beautiful and so wonderful to listen to music, because it stirs a lot with us, with emotions, comes that desire to cry and that strength to believe that everything will be all right. There should be more activities like this here at the hospital (DCS 4).

$\mathrm{Cl}$ 5: Family longing

I listened and went to the door, then entered the room, and it was beautiful. We remember our house, and we miss it, there is a desire to leave, to be at home, hugging our children, wanting to be close to the family. At this time, we realized that, despite being difficult to be here, the music made me feel a relief, because it brings a little of the family presence, brings tranquility. So, if there were more actions like this, it would be much better (DCS 5).

Axis 2 shows how much music mobilizes feelings. In the context of hospitalization, it can make the listener remember and exalt previous experiences - which have the power to renew energies and motivate the individual to better cope with life's difficulties, such as illness. Thus, the experience of being careful with playful elements such as music becomes special.

Listening to music during hospitalization is referred to as wonderful even when the patient feels hopeless. He demonstrates how difficult his internment is being, as she has the ability to bring back hope from meeting with good memories of what has been lived.

AXIS 3: Beyond music - a meeting between care, art and human relations

Cl 6: Art and Care

It would be helpful if the staff used more things like that; not only music, right, but also theater, clowns. It cheers us up a lot, because here we patients are in a sadness, and suddenly people sing. It's very good, I liked it a lot (DCS6).

\section{Cl 7: Touch and Music}

As a suggestion, I think the musical visit should be more dynamic, right, take the patient, which is very good, hug the patient, because I thought it was missing, I thought it was very distant, sang and left, I think you should sing and make movements with the patient, according to the music; this makes the patient feel better. I wanted music all day, if that was the case (laughs), and longer too: it was very fast. I wanted you to sing about ten songs or so. Music has to always have, even if it's a radio on its side, whatever (DCS 7).

Axis 3 presents the expectation of respondents as to the desire to be cared for through touch and artistic methodologies. For them, encountering activities of this nature during their hospitalization represents a differential that they want to encourage in the daily work of professionals who propose to take care of them in their entirety, promoting well-being to their minds and souls, in an attitude transpersonal.

\section{DISCUSSION}

\section{Musical Care at the interface with Transpersonal Care}

The comprehensiveness of care is evidenced by Watson, by the caregiver's commitment to engage with the other, from a subjective and humanized interaction, in which the patient is considered in its entirety. In this perspective, the value of care is present in the caregiver's ability to transform an attitude into an assiduous commitment to being cared for. ${ }^{9}$

Thus, the playful and expressive care should be valued, especially in the contemporary hospital environment, highlighting the need for the development of nurses' skills regarding playful practices. ${ }^{6,16}$ Among them, music can provide relief from pain and suffering by enabling the mobilization of inner energy, which emerges as a flame of hope in the face of problems faced in the hospital environment. ${ }^{5}$

Thus, the use of music as a complementary care strategy is a resource that encourages the soul to direct a more resilient behavior in the face of adversity, by encouraging the spirituality of patients in the face of fear and anguish. While listening to these songs, there is a common desire among them to listen to religious songs, because they are more comforting, helping them to cope with the disease. Religious belief and practice act as facilitators of psychological adjustment. Thus, it is relevant that health professionals welcome the religious contexts of patients and their families, from the understanding of the influence of religiosity on health. ${ }^{17}$ 
However, regardless of the style of musical activities, its implementation within the hospital environment provides patients and staff with pleasure and interaction, as well as contributing to health promotion and preventing injuries. In this context, Caritas Process/Transpersonal Care provides an expanded view of care. It values subjective, creative and artistic aspects in the development of playful musical activities, highlighting a new way of exercising nursing, by enhancing the need for playful care. ${ }^{16}$

Music therapy is revealed as a fruitful possibility for the promotion of innovative care that grasps, beyond the physical dimension, the mind and soul of the human person. Its therapeutic potential is capable of promoting physical and psychological changes, being a qualified instrument in health promotion in health context. ${ }^{18}$

Bringing Jean Watson's theory as the foundation for nursing care enables care to be truly delivered in all its context, as this care constantly values the other in all their aspects and needs. When professionals become able to understand the importance of improving their care practices, their field of action will certainly be expanded. ${ }^{19}$

\section{Music as a rescue element of hope during hospitalization}

The hospitalization process brings out feelings of fear and anxiety of the patient. Faced with this, music becomes a complementary alternative of care when inserted in the hospital context. During hospitalization, it provides comfort and a sense of well-being to the patient, increasing individual care. ${ }^{3}$ Music reduces the negative feelings experienced by the patient, such as anguish, and enables the expression of the most intimate feelings by recalling special situations experienced throughout life..$^{20-21}$

Before image formation, one has the music and its ability to remember memories already lived, places already known, besides telling stories, thrill and inspire those who sing and listen. Therefore, music serves as an instrument to access the patient's insides, strengthen the bonds created during hospitalization and encourage the good times, even in the circumstances surrounding him. ${ }^{22}$

In this sense, it is important to consider aspects such as culture, variety, musical preference and clinical condition of patients in the planning of musical interventions. When the group or practitioners are unaware of the effects music has on people, or the context of patients, the activity can become a major challenge. ${ }^{23}$ Some patients report that certain songs bring back feelings and memories that they would not want to have at the moment. In view of this, sensitivity and individualization are required regarding musical choice, as music will mobilize memories and feelings that may or may not help in coping with the disease. ${ }^{16}$
From this care, music proves to be an efficient and economical therapeutic tool, being accessible, easy to use and without adverse effects, making it used in multiple contexts and as an adjunct in the patient's treatment. ${ }^{24}$ Music leads its listeners to interact with their emotions, which configures the listening moment as a moment of leisure and relaxation, estimated by patients in the setting of such monotony that hospitalization consists. ${ }^{12}$

Another interface provided by music and expressed in this category is the ability of this resource to establish communication with the family. This in its meanings present in the sick being, which evokes the strength and love inherent in his family system, as elements of well-being promotion mediated by music.

In this sense, the meeting promoted by music expands the possibilities of interaction between the subjects involved in the care process. It promotes dialogue by facilitating verbal and nonverbal expression, supporting family members in the elaboration of coping strategies in the transcendence of their vicissitudes, anxieties, sadness and joy, especially when they are away from their homes. In the family context, music emerges as a complementary and multidimensional therapy that influences the mood and mood of the sick person, just as drug therapy is for their suffering. Music feeds spiritually, making the patient and family member experience the presence of God and thus be able to withstand the pain and anguish of emerging adversity. ${ }^{25}$

The benefit of music therapy in the hospital context is also directed to the family. Music brings improvement in weakened beings, as it emerges as an instrument capable of accessing the subjectivity of these individuals, as well as playing a therapeutic role, alleviating the various feelings of fear and anxiety of the patient and their families. ${ }^{25}$

Therefore, musical care is a practice that motivates and rescues affective bonds, increasing the interaction of the professional, the patient and the family. It can encourage the individual to see 4their clinical condition positively, without highlighting their limitations, leading all to overcome the challenges in the care process of this subject.

\section{Beyond music - a meeting between care, art and human relations}

The insertion of art in the context of health care is recommended internationally. Studies state that hospitals must meet the increasingly complex needs of their patients, often with long stays in this space. These studies start from the understanding that overvaluing the focus on physical illness, efficiency, and tasks can divert attention from patients' psychosocial well-being. This concern seeks to encourage the use of approaches that recognize and value the hospitalized person, their life history, their relationships and the context of care. In this sense, the study emphasizes the importance of the arts for health and well-being, alerting professionals in the area to search for these skills and to exercise creativity in addressing the needs of the sick person. ${ }^{6}$ 
The introduction of musical practice in the hospital is one of the possible artistic modalities and provides a better interaction between hospital staff, musicians, the sick and their companions. It favors the bond and promotes a humanized and integrative environment among the actors involved. Music is thus shown to be a beneficial means for human relations, with the ability to transform psychic suffering into a moment of pleasant and comfortable relaxation, providing humanized health care..$^{6,24}$

Therefore, it contributes to the broader care, in a biopsychospiritual proposal, which raises its relevance with the professional practice in the health area, from the moment it is presented as an interactional form of treatment to the hospitalized individual. ${ }^{25}$ Music promotes awareness not only in the patient, but motivates the nursing professional regarding the responsibility of maintaining a therapeutic, more communicative, respectful and ethical environment. ${ }^{6}$

Therefore, music visits promote important benefits for the better relationship between patient, family and staff. For patients, improvement of mood, smiles, improvement of self-esteem, distraction, opportunity to forget, for a few moments, the disease situation to remember good moments; relaxation and tranquility. For the health staff, music promotes relaxation, joy and wellbeing, renewing self-confidence in the care process. ${ }^{26}$ The presence of music in the hospital environment has the power to reduce feelings of sadness, dissatisfaction and discouragement, thus improving the quality of life of the hospital community. In other words, it transforms the hospital's formal environment into a warm and welcoming place. ${ }^{6}$

For all these properties, music can be used as an alternative way to bring people together and welcome. It has the power to facilitate communication, bonding and touch, through which a timely message that is independent of words can be conveyed among those who care and are cared for. ${ }^{27}$

Touch has been the subject of other studies, which already classify it as therapeutic because of its properties in considerably reducing anxiety, fatigue, sleep disturbance and stress and for being a useful treatment in the relief of psychophysiological symptoms. It has a comprehensive care strategy that is increasingly discussed in the health context, but that does not yet integrate care protocols and research effectively. ${ }^{28}$

In this sense, the musical intervention, besides bringing benefits to the patients, also arouses, in the professionals, the reflection on trying new possibilities of intervention, besides the daily practice, which results in self-realization, moments of happiness, satisfaction and pleasure. ${ }^{6}$

By choosing musical care, the professional broadens his or her philosophy of care beyond an act that begins and ends in itself. He challenges himself to care as an attitude that integrates caring, kindness, zeal, interest and commitment, based on sensitivity, appreciation and affection for the other in his multiple care needs. ${ }^{29}$
Thus, Transpersonal Care converges to musical care, aiming for a scientific care model that allows the emergence of an evolved caritas nursing. Thus, nursing develops a deeper appreciation of human complexity and experiences, of inner immersions in one's own life and of the meaning of intersubjective responses to care, healing, illness, despair, disease, and death. It is this model that truly honors and opens the door to the union of mind-body-soul-spirit and our human to human connection as 'Source' that unites us all. ${ }^{10}$

Caritas involves the meaning of appreciation and attention - it represents charity, compassion and generosity. It is indeed something important that needs to be cultivated and sustained in each individual, since caring for the other and showing love is a form of Transpersonal Care, in which the relationship between love and care give access to the caregiver's inner healing and caring..$^{30}$

In this perspective, music, as a care intervention, provides a humanized and comprehensive assistance. In addition to being a resource accessible to hospitals, its use enables interaction between staff and patients, providing the physical and emotional well-being of individuals.

\section{CONCLUSIONS AND IMPLICATIONS FOR THE PRACTICE}

Musical care in the studied context contributed to motivate and rescue the affective bonds, increasing the interaction of the professional, the patient and the family. The strategy was also able to encourage the individual to cultivate spirituality, mobilize his sources of resilience and resize his hope.

As for the implications for practice, the study promotes reflection and guidance for more creative, sensitive and bold care in the hospital environment. It is suggested greater use of music by the health staff, meeting a care extended to human needs that transcend the physical.

It highlights the importance of nursing professionals seeking the development of artistic skills, as well as the interest in producing a creative and expanded care that seeks a therapeutic encounter with the body-mind-soul of the hospitalized person. The search for knowledge of theories of the area, as well as the implementation of their methodologies should be cultivated by these professionals, highlighting the timely association of the Theory of Human Caring as a triggering element of this happy experience.

The study revealed the fruitful relationship between Human Caring and music care, both sharing the goal of promoting hope, faith and resilience in the face of illness or hospitalization, leaving explicit the effects of music on the total body-mind-soul of the human being.

The limitations of this study are related to the restricted context of data apprehension and the cultural and geographical specificities of the study setting. However, the results are relevant because they emerge from a Watson-based extension action assessment proposal that corroborates the national and international literature. 
The development of new research and actions in the area is encouraged, aiming to explore other nuances of this important theme. Investment in the training of nurses is encouraged for greater artistic reflection-action in their care praxis, whether through curricular or even extracurricular activities (research, extension, internships) that maximize the looks and ambitions of these professionals.

\section{CONTRIBUTIONS TO AUTHORS}

Conception of study design. Data acquisition. Analysis and critical interpretation of the results. Writing and critical review of the article. Approval of the published content's final version. Responsibility for the accuracy or completeness of any part of the article: Emanuelle Caires Dias Araújo Nunes

Data acquisition. Analysis and critical interpretation of the results. Writing and critical review of the article. Approval of the published content's final version. Responsibility for the accuracy or completeness of any part of the article: Fabiana Aguiar de Oliveira

Analysis and critical interpretation of the results. Writing and critical review of the article. Approval of the published content's final version. Responsibility for the accuracy or completeness of any part of the article: Juliana Xavier Pinheiro da Cunha, Sabrina Oliveira Reis, Gizelia da Gama Meira, Regina Szylit

\section{ASSOCIATE EDITOR}

Antônio José Almeida Filho

\section{REFERENCES}

1. Ferreira ABH. Dicionário Aurélio Básico da Língua Portuguesa. Rio de Janeiro: Nova Fronteira; 2013.

2. Santos FR, Coronago VMMO. Uso da Musicoterapia como Terapia Alternativa no Tratamento da Doença de Parkinson. Rev Multi Psic [Internet]. 2017 May; [cited 2018 Nov 10]; 11(35):341-60. Available from: https://idonline.emnuvens.com.br/id/article/view/729/1043

3. Campos LF, Nakasu MV. Efeitos da Utilização da Música no Ambiente Hospitalar: revisão sistemática. Rev Sonora [Internet]. 2016; [cited 2018 Nov 10];6(11):9-19. Available from: https://www.publionline.iar.unicamp. br/index.php/sonora/article/view/686

4. Paixão AB, Damasceno TAS, Silva JC. Importância das atividades lúdicas na terapia oncológica infantil. Cuid Arte Enferm [Internet]. 2016 Jul/Dec; [cited 2018 Nov 10]; 10(2):209-16. Available from: http://www. webfipa.net/facfipa/ner/sumarios/cuidarte/2016v2/209-216.pdf

5. Doro MP, Pelaez JM, Dóro CA, Antonechen AC, Malvezzi M, Bonfim CMS, et al. Psicologia e musicoterapia: uma parceria no processo psicoativo dos pacientes do Serviço de Transplante de Medula Óssea. Rev SBPH [Internet]. 2015 Jun; [cited 2018 Jul 15]; 18(1):105-30. Available from: http://pepsic.bvsalud.org/scielo.php?script=sci_ arttext\&pid=S1516-08582015000100006\&lng=pt

6. Silva KG, Martins GCS, Bergold LB. Therapeutic use music to nursing care in a pediatric unit. Rev Enferm UFPI [Internet]. 2016 Jul/Sep; [cited 2018 Nov 10]; 5(3):4-9. Available from: http://www.ojs.ufpi.br/ index.php/reufpi/article/view/5362/pdf. DOI: http://dx.doi.org/10.12957/ reuerj.2017.26265

7. Tejon JL. Música, a esperança sem dor. In: Leão ER. Cuidar de pessoas e música, uma visão multiprofissional. São Caetano do Sul (SP):Yendis Editora; 2009. p. 1-10.
8. Nascimento CAA, Filho Crepalde NJB. A Música Como Recurso nos Processos de Humanização Hospitalar. Rev Form Doc [Internet] 2015; [cited 2018 Nov 10]; 7(1):24-35. Available from: https://www. researchgate.net/publication/279449695_A_Musica_como_Recurso_ nos_Processos_de_Humanizacao_Hospitalar DOI: 10.15601/22370587/fd.v7n1p24-35

9. Rohr RV, Alvim NAT. Intervenções de enfermagem com música: revisão integrativa da literatura. J Res Fundam Care Online [Internet]. 2016 Jan/ Mar;8(1):3832-44. Available from: http://www.seer.unirio.br/index.php/ cuidadofundamental/article/view/4182/pdf 1797. DOI: 10.9789/21755361.2016.v8i1.3832-3844

10. Yurkovich J, Burns DS, Harrison T. The Effect of Music Therapy Entrainment on Physiologic Measures of Infants in the Cardiac Intensive Care Unit: Single Case Withdrawal Pilot Study. J Music Ther [Internet]. 2018; [cited 2018 Jul 15]; 55(1):62-82. Available from: https://academic.oup.com/jmt/ article-abstract/55/1/62/4920858? redirectedFrom=fulltext. DOI: http:// dx.doi.org/10.1093/jmt/thx017

11. Rosa W, Estes T, Watson J. Caring Science Conscious Dying: An Emerging Metaparadigm. Nurs Sci Q [Internet]. 2016 Dec; [cited 2018 Aug 1]; 30(1):58-64. Available from: http://journals.sagepub.com/ doi/abs/10.1177/0894318416680538?url_ver=Z39.88-2003\&rfr id=ori:rid:crossref.org\&rfr_dat=cr_pub\%3dpubmed. DOI: http://dx.doi. org/10.1177/0894318416680538

12. Watson J. Enfermagem: ciência humana e cuidar uma teoria de enfermagem. Trad. João Enes. Portugal: Lusociência; 2002.

13. Vasconcelos A, Costa LMP. Representações sociais da música: formação x educação. Rev Ciênc Hum UNITAU [Internet]. 2018 Jun [cited 2019 Aug 5]; 11(1):19-31. Available from: https://www.rchunitau. com.br/index.php/rch/article/view/439. DOI: http://dx.doi.org/10.32813/ rchv11n12018artigo2

14. Moscovici S. Representações sociais: investigações em psicologia social. 9a ed. Petrópolis: Vozes; 2011.

15. Lefévre F, Lefévre AMC. Discurso do sujeito coletivo: um novo enfoque em pesquisa qualitativa (Desdobramentos). $2^{a}$ ed. Caxias do Sul: Educs 2005.

16. Ford K, Tesch L, Dawborn J, Courtney-Pratt H. Art, music, story: The evaluation of a person-centred arts in health programme in an acute care older persons' unit. Int J Older People Nurs [Internet]. 2018 Jun [cited 2018 Aug 1]; 13(2):e12186. Available from: https://onlinelibrary. wiley.com/doi/abs/10.1111/opn.12186. DOI: http://dx.doi.org/10.1111/ opn.12186

17. Silva SK, Passos SMK, Souza LDM. Associação entre religiosidade e saúde mental em pacientes com HIV. Psicol Teor Prat [Internet]. 2015 Aug; [cited 2018 Feb 10]; 17(2):36-51. Available from: http:// pepsic.bvsalud.org/scielo.php?script=sci_arttext\&pid=S151636872015000200003\&lng=pt\&tlng=pt

18. Sousa ADRS, Silva LF, Paiva ED. Nursing interventions in palliative care in Pediatric Oncology: an integrative review. Rev Bras Enferm [Internet]. 2019 Apr; [cited 2019 May 30]; 72(2):531-40. Available from: http://www.scielo.br/scielo.php?script=sci_arttext\&pid=S003471672019000200531\&lng=en. DOI: http://dx.doi.org/10.1590/00347167-2018-0121

19. Savieto RM, Leão ER. Nursing assistance and Jean Watson: a reflection on empathy. Esc Anna Nery [Internet]. 2016 Jan/Mar; [cited 2019 May 30]; 20(1):198-202. Available from: http://www.scielo.br/scielo. php?script=sci_arttext\&pid=S1414-81452016000100198\&lng=en. DOI: http://dx.doi.org/10.5935/1414-8145.20160026

20. Fallavigna D, Bellaguarda MLR, Gaio TC, Rosa MC. A música na assistência à saúde de pacientes em cuidados paliativos. Rev Eletr Est Saúde [Internet]. 2016; [cited 2017 Apr 20]; 5(1):190-201. Available from: http://periodicos.estacio.br/index.php/saudesantacatarina/article/ viewFile/2240/1065

21. Reychler G. Mottart F, Boland M, Wasterlain E, Pieters T, Caty G, et al. Influence of Ambient Music on Perceived Exertion During a Pulmonary Rehabilitation Session: A Randomized Crossover Study. Respir Care [Internet]. 2015 May; [cited 2018 Feb 10]; 60(5):711-7. Available from: http://rc.rcjournal.com/content/60/5/711.short. DOI: http://dx.doi. org/10.4187/respcare.03671 
22. Nogueira W, Escrich F, Figueiredo R, Saíde S, Ferrara T. Música na atividade clown. In: Leão ER, org. Cuidar de pessoas e música, uma visão multiprofissional. São Caetano do Sul:Yendis Editora; 2009. p. 309-20.

23. Silva MJP. A música no controle da dor crônica. In: Leão ER, org. Cuidar de pessoas e música, uma visão multiprofissional. São Caetano do Sul:Yendis Editora; 2009. p. 139-58.

24. Silva LAGP, Baran FDP, Mercês NNA. Music in the care of children and adolescents with cancer: integrative review. Texto Contexto Enferm [Internet]. 2016 Nov; [cited 2019 May 30]; 25(4):E1720015. Available from: http://www.scielo.br/scielo.php?script=sci_arttext\&pid=S010407072016000400308\&lng=en. DOI: http://dx.doi.org/10.1590/010407072016001720015

25. Silva VA, Marcon SS, Sales CA. Perceptions of family members of patients with cancer on musical encounters during the antineoplastic treatment. Rev Bras Enferm [Internet]. 2014 May/Jun; [cited 2017 Jul 12]; 67(3):408-14. Available from: http://www.scielo.br/scielo. php? script=sci_arttext\&pid=S0034-71672014000300408\&lng=pt. DOI: http://dx.doi.org/10.5935/0034-7167.20140054
26. Claro LBL, Netto DV, Valente LR. Perceptions of patients and health care professionals about the visits paid by the outreach program "good night, good morning HUAP”. Rev Con UEPG (Ponta Grossa) [Internet] 2017; [cited 2018 Jun 20]; 13(1):66-83. Available from: http://www. revistas2.uepg.br/index.php/conexao/article/view/9278/5495. DOI: http://dx.doi.org/10.5212/Rev.Conexao.v.13.i1.0005

27. Rezende RC, Oliveira RMP, Araújo STC, Guimarães TCF, Santo FHE, Porto IS. Body language in health care: a contribution to nursing communication. Rev Bras Enferm [Internet]. 2015 May/Jun; [cited 2019 May 30]; 68(3):490-6. Available from: http://www.scielo.br/scielo. php?script=sci_arttext\&pid=S0034-71672015000300490\&lng=en. DOI: http://dx.doi.org/10.1590/0034-7167.2015680316i

28. Mello TCA, Brito RS. Efetividade do toque terapêutico no alívio de sintomatologia do paciente. Saúde (Santa Maria) [Internet] $2015 \mathrm{Jul} /$ Dec; [cited 2018 Jun 20]; 41(2):45-52. Available from: https://periodicos. ufsm.br/revistasaude/article/view/14472/pdf_1. DOI: http://dx.doi. org/10.5902/2236583414472

29. Boff L. Saber cuidar. $20^{\mathrm{a}}$ ed. Rio de Janeiro: Vozes; 2014.

30. Watson J. Nursing: the philosophy and science of caring. Rev ed. Boulder: University Press of Colorado; 2008. 